Article

\title{
Diversity of NC10 Bacteria and ANME-2d Archaea in Sediments of Fault Zones at Lake Baikal
}

\author{
Anna Lomakina ${ }^{1, *}$, Tatyana Pogodaeva ${ }^{1}\left(\mathbb{D}\right.$, Gennady Kalmychkov ${ }^{2}$, Svetlana Chernitsyna ${ }^{1}$ \\ and Tamara Zemskaya ${ }^{1}$ (D) \\ 1 Limnological Institute, Siberian Branch, Russian Academy of Sciences, 664033 Irkutsk, Russia; \\ tatyana@lin.irk.ru (T.P.); sveta@lin.irk.ru (S.C.); tzema@lin.irk.ru (T.Z.) \\ 2 Vinogradov Institute of Geochemistry, Siberian Branch, Russian Academy of Sciences, 664033 Irkutsk, \\ Russia; gkalm@igc.irk.ru \\ * Correspondence: lomakina@lin.irk.ru; Tel.: +7-950-0512223
}

Received: 30 October 2019; Accepted: 19 December 2019; Published: 20 December 2019

\begin{abstract}
Anaerobic oxidation of methane (AOM) reduces methane emissions from marine ecosystems, but we know little about AOM in freshwater reservoirs. Lake Baikal is the world's only freshwater reservoir where gas hydrates $(\mathrm{GH})$ are found. Despite that AOM has been demonstrated in deep sediments of Lake Baikal did not reveal methane-oxidizing archaea ANME1, 2, or 3, which are responsible for AOM in marine sediments. A search for representatives Candidatus Methylomirabilis oxyfera (M. oxyfera)-like bacteria (NC10) and Candidatus Methanoperedens nitroreducens ( $M$. nitroreducens)-like archaea (ANME-2d) has been carried out in the different types of Lake Baikal methane enriched sediments. We used different molecular biology methods including high-throughput sequencing and PCR analysis, using $16 \mathrm{~S}$ rRNA genes as well as different functional genes of AOM ( $m c r A$ and $p m o A)$. We found diverse M. oxyfera-like bacteria and M. nitroreducens-like archaea in various geological structures in Lake Baikal (methane seep and mud volcano), which were different from the composition of the discharged fluid. We also considered possible electron acceptors for this process in the sediments of Lake Baikal.
\end{abstract}

Keywords: anaerobic oxidation of methane; Lake Baikal; high-throughput sequencing of the 16S rRNA gene; $p m o A$ gene; $m c r A$ gene; Candidatus Methanoperedens nitroreducens (ANME-2d); Candidatus Methylomirabilis oxyfera (NC10)

\section{Introduction}

Lake sediments are globally important carbon storages [1,2], but they are also important contributors of methane $\left(\mathrm{CH}_{4}\right)$ to the atmosphere [3]. Approximately $70 \%$ of atmospheric methane is of microbial origin. $\mathrm{CH}_{4}$ emissions from these environments are controlled by both methanogenesis and $\mathrm{CH}_{4}$ oxidation. Methanotrophs oxidize the resulting methane under both aerobic and anaerobic conditions, decreasing significantly the emission of this greenhouse gas into the atmosphere. In the presence of oxygen, widespread methanotrophic species of Alpha- and Gammaproteobacteria, which have the key enzyme of a methylotrophic pathway (methane monooxygenase), oxidize methane [4-9]. Aerobic methanotrophs were also described within the phylum Verrucomicrobia [10].

The process of AOM was described long ago [11-14]. Currently, the most studied processes are sulfate-dependent methane oxidation via the reverse methanogenesis pathway performed by archaea of the ANME clusters in marine sediments [15-17]. Approximately $90 \%$ of $\mathrm{CH}_{4}$ is assimilated through anaerobic oxidation by ANME clusters $[16,18]$. There are three known ANME archaea clusters (ANME1, 2 and 3), which were further divided into subclusters. ANME-1 and ANME-2 are very widespread in marine sediments, whereas members of ANME-3 are mainly found in deep mud 
volcanoes. The highest density of methanotrophic archaeal populations is observed in cold methane seeps [16].

In recent years, there has been an active search for microbial agents that carry out AOM in freshwater ecosystems. Recent studies have shown that in oxygen-free soil layers and bottom sediments, anaerobic methanotrophic bacteria, and/or archaea, which are used as electron acceptors of nitrite or nitrate ions, consume methane [19-24]. Methane oxidation under anaerobic conditions, which is associated with nitrite reduction, was first demonstrated in the enrichment cultures derived from freshwater sediments [23]. Microorganisms responsible for this process were classified as bacteria that belong to the candidate phylum NC10 [21] and are named M. oxyfera. Usually, the 16S rRNA gene is applied as a biomarker for analyzing NC10 bacteria [21]. However, the $p m o A$ gene catalyzes the aerobic conversion of methane to methanol, is highly conserved, and can be applied as a functional marker to identify NC10-like bacteria [25]. Furthermore, nitric oxide dismutase (nod) functional gene can be also as phylogenetic marker for oxygenic methanotrophs within the NC10 phylum [26]. Analyses of various environmental samples using primers on the $p m o A$ and nod genes have indicated $M$. oxyfera various anoxic environments including lake sediments, wastewater treatment systems [27-31]. Members of the ANME-2d subcluster named M. nitroreducens perform AOM using nitrate as the terminal electron acceptor $[19,22]$. The resulting nitrite is reduced to gaseous nitrogen due to syntrophic interaction with ANAMMOX-bacteria (in the presence of ammonium) or with M. oxyfera (phylum NC10) [32]. Nitrate, being a product of anammox process can be reused by members of ANME-2d, which are widespread in environments and detected in freshwater ecosystems, soils, paddy fields, and treatment plants [22,23,33-35]. M. nitroreducens consist of all genes of the reverse methanogenic pathway (morABCDG) [22,36].

Although the $16 \mathrm{~S}$ rRNA gene is most commonly used for phylogenetic analysis, the $m c r A$ gene is an alternative and more specific biomarker for detecting not only methanogens but ANMEs clusters in the environments. Previously published $m c r A$ primers were designed to mainly target all known methanogens and methanotrophic archaea, and most of them have a strong bias toward certain methanogens or specific groups of ANMEs [37-40]. Available general $m c r A$ primers do not suit well to capture $m c r A$ sequences of ANME-2d in the nature, potentially resulting in under representation in molecular investigation. Therefore, for detection of $m c r A$ sequences in the environment, novel $m c r A$ primers were developed, which specifically target $M$. nitroreducens for refined phylogenetic analysis [41].

More ANME sequences in different environments and possibly new archaeal phyla involved in AOM may yet have to be detected. For example, in genomes representatives Bathyarchaeota and Verstraetearchaeota the $m c r A$ genes were found [42,43]. Sequences of phylum Verstraetearchaeota were detected in two habitats: a mesophilic methanogenic granular sludge reactor and deep sediment of the freshwater Lake Pavin (France). $\mathrm{Fe}^{3+}, \mathrm{Cr}^{4+}$, and $\mathrm{Mn}^{4+}$ may also act as electron acceptors in the course of anaerobic methane oxidation, but the mechanisms of these processes have not been determined yet $[33,34,44]$. Fe(III)-dependent AOM is likely a prevalent process both marine $[20,45]$ and freshwater [46] ecosystems, where large amounts of iron oxides are detected in the sediments. Iron and manganese ions were present in freshwater lakes that lack $\mathrm{SO}_{4}{ }^{2-}$ and $\mathrm{NO}_{3}{ }^{-}$ions and where $\mathrm{AOM}$ was detected [47,48]. Some representatives of ANME-2d have also been reported coupling $\mathrm{CH}_{4}$ oxidation to the reduction of $\mathrm{Mn}^{4+}$ and/or $\mathrm{Fe}^{3+}$ [44,49]. One of the first study sites that provides information about AOM activity in freshwater sediments is Lake Ørn. In the sediments of this lake, which are characterized by low concentrations of $\mathrm{SO}_{4}{ }^{2-}$ and $\mathrm{Fe}^{2+}$ ions [47,50], ANME-2d subcluster sequences were detected [24] in the absence of nitrate ions. This finding suggests that $M$. nitroreducens-like archaea perform AOM coupled to sulfate and/or iron reduction and may be capable of assimilation of $\mathrm{CH}_{4}$ and dissolved inorganic carbon. Thus, ANME-2d archaea play an important role in controlling methane emissions from freshwater systems with low concentration $\mathrm{NO}_{3}{ }^{-}$and $\mathrm{SO}_{4}{ }^{2-}$ ions [24].

Lake Baikal is the world's only freshwater reservoir where gas hydrates $(\mathrm{GH})$ are found, and it describes more than 50 geological structures that differ in the composition of the discharged 
fluids [51,52]. In deep sediments near GH, the rate of AOM ranged from 35 to $273.2 \mu \mathrm{L} \mathrm{CH}_{4} /\left(\mathrm{dm}^{3}\right.$ day) [53], increasing at depths of 20-60 cm, which may indicate the functioning of the anaerobic community of microorganisms [54-56]. The process of AOM in deep sediments of Lake Baikal was detected by radioisotope techniques, with a maximum that was usually close to the GH layers, as well as by the shape of methane profile with depth typical for AOM [56,57]. Despite high methane concentrations in deep sediments of some sites of Lake Baikal (up to $15000 \mu \mathrm{M}$ ) that are sufficient to carry out of AOM [58], members of methane-oxidizing ANME clusters were not detected [57,59,60]. In this regard, it was suggested that the process could be carried out in methane-enriched freshwater lake sediments by other microorganisms, including ANME-2d archaea and NC10 bacteria. The latest study showed the simultaneous presence of these phyla in enrichment culture with nitrate ions as a nitrogen source in AOM [61] and in enrichment Baikal cultures obtained from the cultivation of the microbial community from the mud volcano Peschanka (Southern Baikal) [62]. Chemical analysis of pore water deep sediments from Lake Baikal generally indicated the absence or low concentrations of nitrate and nitrite ions (up to $9.6 \mu \mathrm{M}$ ) [56,63], which is insufficient for AOM. Therefore, the question about the presence of electron acceptors and microbial agents that carry out AOM remains open, and it is unclear which of the known mechanisms of this process dominate in the deep sediments of Lake Baikal.

The aim of this study was to detect representatives of the ANME-2d subcluster and NC10 bacteria in Baikal sediments with different types of geological structures, which discharge sulfate-calcium and sodium-calcium fluids with increased concentrations of $\mathrm{Fe}^{2+}$ and $\mathrm{NH}^{4+}$, as well as to determine the presence of functional AOM genes in their genomes $(m c r A$ and $p m o A$ ) using methods of high-throughput sequencing and PCR analysis.

\section{Materials and Methods}

\subsection{Description of Sampling Sites, Sample Collection, and Pretreatment}

Sediment samples were collected during the 2010 and 2012 expeditions on board the research vessel (RV) "G.Yu. Vereshchagin" using the gravity corer (GC) at two geomorphologically distinct sites: the mud volcano Malenky (M, 1371 water depth) and the methane seep Posolsk Bank (PB, $400 \mathrm{~m}$ ) (Figure 1). GH layers occurred in the sediments of the mud volcano $M$ at depths from 130 to $139 \mathrm{~cm}$ and between 100 and $140 \mathrm{~cm}$ in those, the methane seep PB. After lifting the core onto the RV board and cutting it into two lengthwise halves, the sediment samples were collected for chemical analysis of pore waters and DNA extraction. Bottom sediments selected for DNA extraction were stored in liquid nitrogen until the laboratory analysis. 


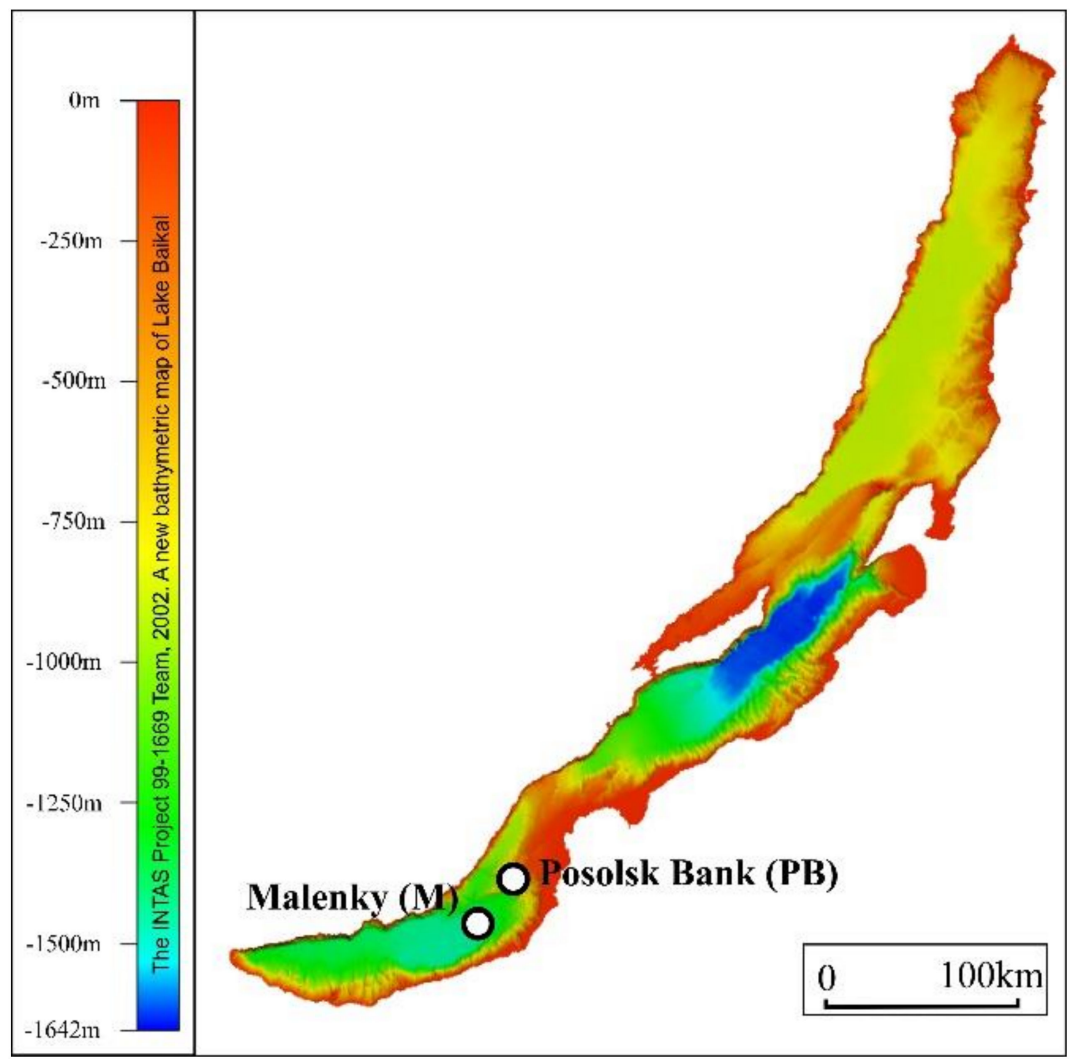

Figure 1. Sampling sites in Lake Baikal. Methane seep, Posolsk Bank (52.03 N, 105.84 E); a mud volcano, the Malenky (51.92 N, 105.63 E).

\subsection{Measurements of Methane Concentrations and Analysis of the Chemical Composition of Pore Waters}

Methane concentrations in the sediments were determined using headspace analysis [64] on an EKhOPID chromatograph equipped with a flame ionization detector (2-m packed column, internal diameter $2 \mathrm{~mm}$, Porapak as the sorbent, and isothermal mode at $100{ }^{\circ} \mathrm{C}$ ). The measurement error for methane concentration was $\pm 5 \%$.

Pore water extractions were obtained from 9 samples (100 g each), which were collected throughout the core. Pore waters were obtained on board the ship by sequential centrifuging the sample for 20 min at $5000 \mathrm{~g}$, then for $10 \mathrm{~min}$ at $12,000 \mathrm{~g}$. The pore water anion and cation contents were determined the methods described previously and are only briefly repeated here $[57,65,66]$. Pore water anion $\left(\mathrm{SO}_{4}{ }^{2-}, \mathrm{NO}_{3}{ }^{-}, \mathrm{HCO}_{3}{ }^{-}\right.$, and $\left.\mathrm{CH}_{3} \mathrm{COO}^{-}\right)$concentrations were measured onboard the ship by means of liquid chromatography immediately after preparation (5-10\% relative error). The detection limits were $0.1 \mathrm{mg} / \mathrm{L}$. The ions $\mathrm{NO}_{2}{ }^{-}$and $\mathrm{NH}_{4}{ }^{+}$were determined onboard the ship by colorimetric methods $(5 \%$ relative error). The detection limits were $0.003 \mathrm{mg} / \mathrm{L}$ for $\mathrm{NO}_{2}{ }^{-}$and $0.05 \mathrm{mg} / \mathrm{L}$ for $\mathrm{NH}_{4}{ }^{+}$. The pore water samples for $\mathrm{Fe}^{2+}$ analysis were stored at $4{ }^{\circ} \mathrm{C}$ in polystyrene vials pre-acidified with $50 \mu \mathrm{L}$ of ultra-pure concentrated $\mathrm{HNO}_{3}$. The $\mathrm{Fe}^{2+}$ concentrations were determined by atomic absorption method (3-5\% relative error) in the laboratory LIN SB RAS. The detection limit was $0.01 \mathrm{mg} / \mathrm{L}$.

\subsection{Molecular Analyses}

DNA was extracted according to phenol-chloroform method [67] in a modified version [68] from five samples of the PB site: the surface layer and the layers from depths of 10, 70, 100, and $140 \mathrm{~cm}$; the $\mathrm{M}$ site-the surface layer and the layers of 60-65, 130-131, 132-139, and 140-146 cm. For PCR analyses were used primers for the mcrA gene of ANME-2d subcluster and methanogenic archaea were used, as well as for $16 \mathrm{~S}$ rRNA and pmoA gene of NC10 bacteria (Table 1). 
Table 1. PCR primers used for $m c r A$, $p m o A$, and $16 \mathrm{~S}$ rRNA genes amplification. PCR reaction conditions are shown in references.

\begin{tabular}{|c|c|c|c|}
\hline Primer & Detected Microbial Groups & Sequence $\left(5^{\prime}-3^{\prime}\right)$ & References \\
\hline $\begin{array}{l}159 \mathrm{~F} \\
345 \mathrm{R}\end{array}$ & ANME-2d $m c r A$ gene & $\begin{array}{l}\text { AAAGTGCGGAGCAGCAATCACC } \\
\text { TCGTCCCATTCCTGCTGCATTGC }\end{array}$ & [41] \\
\hline $\begin{array}{l}\text { NC10-202Fdeg } \\
\text { NC10-1043Rdeg }\end{array}$ & NC10 16S rRNA gene & $\begin{array}{c}\text { RACCAAAGGRGGCGAGCG } \\
\text { TCTCCRCGYTCCCTTGCG }\end{array}$ & [27] \\
\hline $\begin{array}{l}\text { A189F } \\
\text { NA720R }\end{array}$ & NC10 pmoA gene & $\begin{array}{l}\text { GGNGACTGGGACTTCTGG } \\
\text { TCCCCATCCACACCCACCAG }\end{array}$ & {$[27,69]$} \\
\hline $\begin{array}{l}\text { pUC/M13F } \\
\text { pUC/M13R }\end{array}$ & Universal group & $\begin{array}{l}\text { GTTTTCCCAGTCACGAC } \\
\text { CAGGAAACAGCTATGAC }\end{array}$ & $\begin{array}{l}\text { Promega } \\
\text { Promega }\end{array}$ \\
\hline $\begin{array}{l}\text { A2Fa } \\
\text { A519R }\end{array}$ & Archaea 16S rRNA gene & $\begin{array}{c}\text { TTCCGGTTGATCCYGCCRGA } \\
\text { GGTDTTACCGCGGCKGCKGCTG }\end{array}$ & {$[70]$} \\
\hline
\end{tabular}

PCR fragments were cloned in the competent cells of E. coli DH5 $\alpha$. The purified amplification products $16 \mathrm{~S}$ rRNA, pmoA, mcrA genes of bacteria, and archaea were cloned into the pGEM_T Easy Vectors plasmid vector (Promega, USA) according to the manufacturer's specifications. Transformation of the competent cells was carried out according to the standard procedure [67]. The clones with the PCR fragment inserts ( 15 to 25 clones per each of the four libraries) were selected using Xgal/IPTG. Plasmid DNA was isolated from $12 \mathrm{~h}$ cultures of E. coli DH5 $\alpha$ grown in liquid LB medium with ampicillin $(50 \mathrm{U} / \mathrm{mL})$. The plasmid DNA samples were stored at $-18{ }^{\circ} \mathrm{C}$. For confirmation of the existence of inserts of the necessary size, plasmid primers were used (Table 1).

The amino acid and nucleotide sequences of independent clones were determined via Sanger method using BigDye Terminator Kit v.3.1 (Applied Biosystems) and genetic analyzer ABI 3130x1 at SB RAS Genomics Core Facility (ICBFM SB RAS, Novosibirsk, Russia).

Initial analysis of the similarity of the 16S rRNA gene sequences to the known GenBank sequences (http://www.ncbi.nlm.nih.gov/genbank/) was carried out using the BLAST software package. Amino acid sequences of the $m c r A$ and $p m o A$ genes were obtained online at http://web.expasy.org/translate/. Chimeral sequences of the 16S rRNA genes were excluded using the Pintail online system (http: //www.bioinformaticstoolkit.org/WebPintail/). The operational taxonomic units (OTUs), comprising the sequences with at least $98 \%$ similarity, were accepted as the phylotypes that represent the members of the community at the species level. These OTUs were used for further analysis. Sequences were edited using BioEdit. Nucleotide (gene 16S rRNAof NC10 bacteria) and amino acid ( $m c r A, p m o A)$ sequences were aligned using the CLUSTALW algorithm. Corresponding phylogenetic trees were constructed by the NJ and Kimura two-parameter methods implemented in MEGA version 6.0 [71].

The sequences determined in this study for NC10 phylum specific $16 \mathrm{~S}$ rRNA, pmo $A$, and $m c r A$ genes for anaerobic methanotroph archaeon have been deposited in the GenBank database under accession numbers MN595984-MN596011, MN603447-MN603470, and MN595903-MN595983 respectively.

\section{4. $16 \mathrm{~S}$ rRNA Gene High-Throughput Sequencing of Archaeal Communities}

For amplification of archaeal 16S rRNA gene fragments, the primers for the V1-V3 region (Table 1) were used. Pyrosequencing of the amplicons was carried out on a GS FLX 454 genome analyzer (Roche, United States). Diversity and taxonomic composition of archaeal communities were analyzed using the Mothur v. 1.31.2 software package. For this purpose, the sequences were aligned, and cluster analysis was carried out. The sequences were grouped into operational taxonomic units (OTUs) at genetic distances of 0.03 . The taxonomic position of the representative sequences in a cluster with a genetic distance of 0.03 was determined by comparison to the following $16 \mathrm{~S}$ rRNA databases: SILVA and NCBI. For analysis of molecular genetic diversity of the community, the following values were calculated: number of observed OTUs. The obtained sequences were processed by the PyroNoise algorithm [72] to remove sequencing errors. Chimeric sequences were detected using the UCHIME algorithm [54] with standard parameters. Pyrosequencing of the $16 \mathrm{~S}$ rRNA gene V1-V3 region yielded 27,231 sequences 
for deep sediments $\mathrm{M}$ and 12,154 sequences for deep sediments PB after initial filtration, alignment of reads, and the removal of chimeric sequences. Sequences shorter than $180 \mathrm{bp}$ were excluded from analysis. Comparison with the known $16 \mathrm{~S}$ rRNA gene sequences was carried out using BLASTN. The sequence arrays were deposited to GenBank, SRA section, under accession nos. SRR2912890 (Archaea, PB) and SRP052288 (Archaea, M).

\section{Results}

\subsection{Chemical Composition of Pore Waters}

Sediments of the investigated core from the methane seep PB were highly saturated with gas. Methane concentration increased with depth (up to $10 \mu \mathrm{M}$ in surface sediments), reaching maximum values (up to $9000 \mu \mathrm{M}$ ) in the sedimentary strata where GHs were detected (Figure 2). Throughout the core, there were increased concentrations of $\mathrm{CH}_{3} \mathrm{COO}^{-}$ions up to $379 \mu \mathrm{M}$ and $\mathrm{Fe}^{2+}$ up to $134 \mu \mathrm{M}$. The concentration of $\mathrm{NH}_{4}{ }^{+}$ions in pore waters from the investigated station varied from $16.7 \mu \mathrm{M}$ to $205.5 \mu \mathrm{M}$, and the highest $\mathrm{NH}_{4}{ }^{+}$concentrations were in deep layers of the bottom sediments at the boundary with $\mathrm{GHs}(70 \mathrm{~cm})$. The concentrations of $\mathrm{SO}_{4}{ }^{2-}$ ions in pore waters from the investigated core had maximum values in the surface sediments $(62 \mu \mathrm{M})$. Pore water $\mathrm{NO}_{3}{ }^{-}$content was $20 \mu \mathrm{M}$ in surface sediments, and it was not detected in other pore waters.

In addition to GHs, bottom sediments of the mud volcano $\mathrm{M}$ contained carbonate (oligonite - Fe(Mn, $\left.\mathrm{Zn})\left(\mathrm{CO}_{3}\right)_{2}\right)$ at a depth of $145 \mathrm{~cm}$, whose structure was determined on a JCXA-733 wave $X$-ray microanalyzer at the Institute of Geochemistry SB RAS. Unlike the methane seep PB, methane concentrations in sediments of the mud volcano M exceeded $90 \mu \mathrm{M}$ almost from the surface and showed uneven distribution with the maximum value at a depth of $140 \mathrm{~cm}$ (up to $1200 \mu \mathrm{M}$ ) (Figure 2). The concentrations of $\mathrm{SO}_{4}{ }^{2-}$ in pore waters of the investigated core reached $3781 \mu \mathrm{M}$ in sediments that contained carbonate $(140-146 \mathrm{~cm})$; the minimum concentrations were recorded in GH layers (130-131 cm and 132-139 cm). Higher concentrations of $\mathrm{HCO}_{3}{ }^{-}$ions in comparison with the reference values (up to $1098 \mu \mathrm{M}$ ) are typical of all studied sediments with the maximum in GH layer of 130-131 cm (up to $4049 \mu \mathrm{M}$ ). We did not detect $\mathrm{NO}_{3}{ }^{-}$and $\mathrm{CH}_{3} \mathrm{COO}^{-}$ions there, which were present in sediments of the methane seep PB. Notably, unlike the methane seep PB, all layers of the investigated sediments had lower concentrations of $\mathrm{Fe}^{2+}$ ions with the maximum values of $19.64 \mu \mathrm{M}$ in $\mathrm{GH}$ layer $(130-131 \mathrm{~cm})$. 

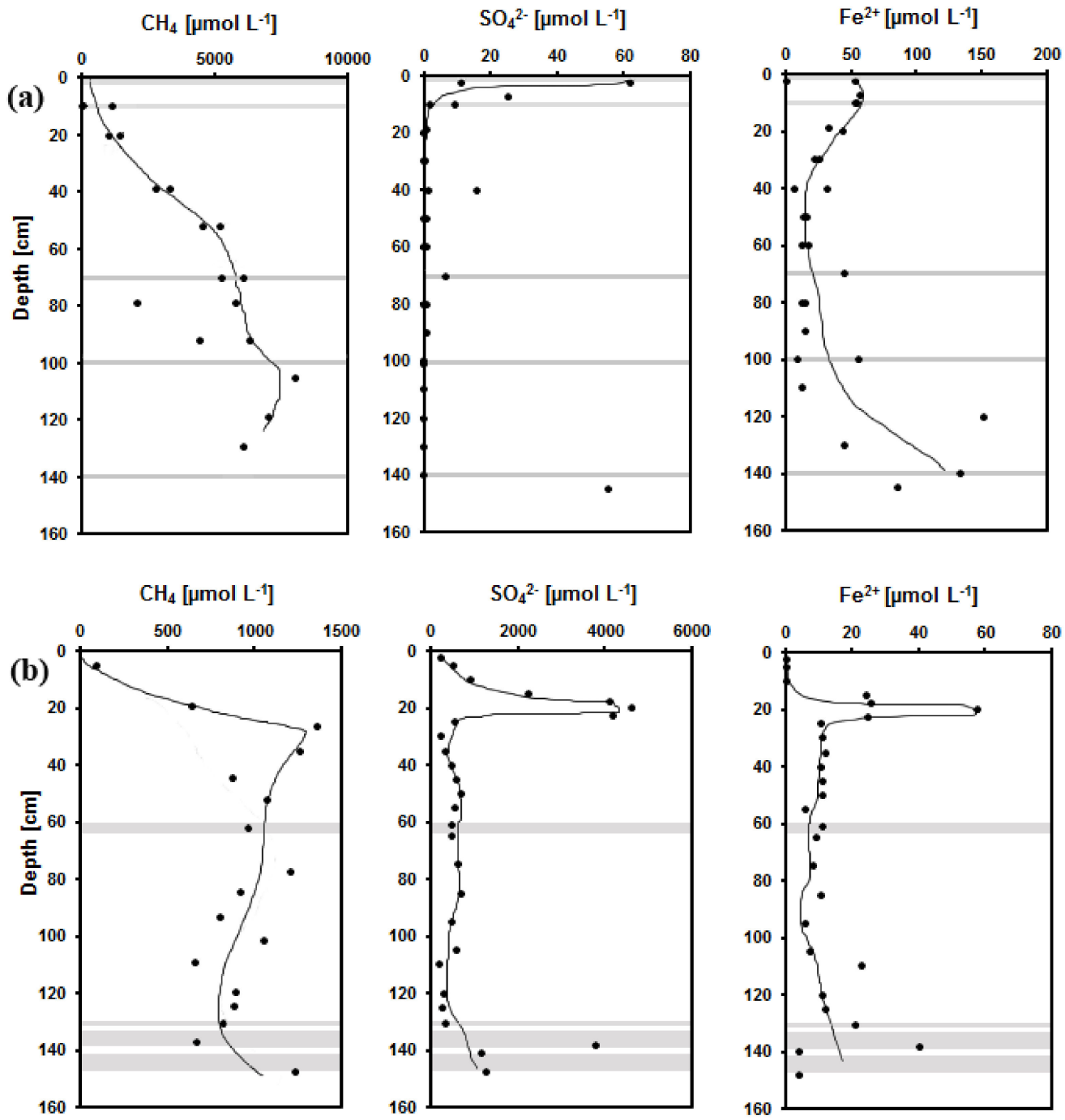

Figure 2. Concentration depth profiles of methane $\left(\mathrm{CH}_{4}\right)$, sulfate ions $\left(\mathrm{SO}_{4}{ }^{2-}\right)$, and dissolved iron $\left(\mathrm{Fe}^{2+}\right)$, (a) the methane seep Posolsk Bank; (b) the mud volcano Malenky. Samples of bottom sediments taken for molecular biological studies are highlighted.

\subsection{Diversity of the ANME-2d $16 S$ rRNA Genes in Libraries}

Near the mud volcano M, we detected the representatives of the ANME-2d subcluster in all obtained DNA samples. Whereas in site of the methane seep PB we not detected sequences of the ANME-2d in sediments $100 \mathrm{~cm}$ and $140 \mathrm{~cm}$. The number of OTUs varied from one to five per one analyzed sample. In the phylogenetic tree, the recovered nucleotide 16S rRNA gene sequences formed six clusters, and one cluster was common for DNA from the two investigated sites.

Analysis of 16S rRNA gene libraries of the ANME-2d subcluster has shown that near the mud volcano $\mathrm{M}$, the bulk of the genes ( $22 \%$ and $20 \%$ of all analyzed sequences) was in sediments with GHs $(130-131 \mathrm{~cm})$ and oligonite $(140-146 \mathrm{~cm})$, respectively. At a depth of 60-65 cm, we detected approximately $15 \%$ of the ANME-2d $16 \mathrm{~S}$ rRNA gene sequences, and in sediments adjacent to GHs $(132-139 \mathrm{~cm}$ ) their quantity was approximately $6 \%$ (Figure 3 ). 


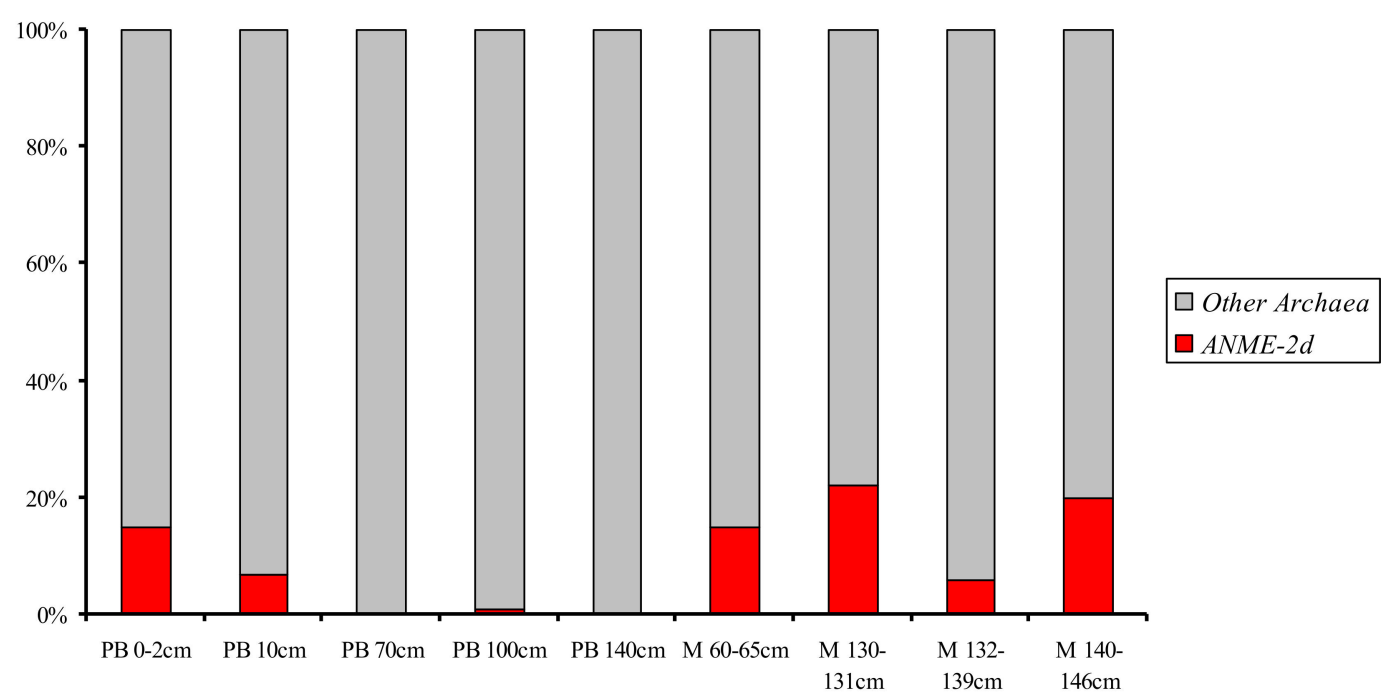

Figure 3. Share of archaea of the ANME-2d subcluster in archaeal communities from bottom sediments.

Nucleotide sequences of $16 \mathrm{~S}$ rRNA gene fragments of the ANME-2d representatives in the sediments of the methane seep PB predominated in the surface sediment $(0-2 \mathrm{~cm})$, decreasing with depth to $6.8 \%$ at $10 \mathrm{~cm}$, and to $1 \%$ at $100 \mathrm{~cm}$. Notably, we did not detect the ANME-2d sequences in the DNA samples taken from depths of 70 and $140 \mathrm{~cm}$ (Figure 3).

Analysis of 16S r RNA gene libraries of the ANME-2d subcluster has indicated the most diverse nucleotide sequences from the DNA sample from the surface layer of the methane seep $\mathrm{PB}$, which were combined into five OTUs (Figure 4). Approximately 13\% of all ANME-2d sequences (OTU16) from this sediment layer formed a cluster in the phylogenetic tree with sequences from marine sediments of the western cold sea, the Weddell Sea, Antarctica (Acc. no. FN429785); 4\% of sequences (OTU74) formed a cluster with denitrifying anaerobic methane oxidation archaea [19]; the remaining sequences (approximately $2 \%$ of all analyzed ANME-2d sequences, OTU101) grouped with sequences of archaea from sediments of Honghu Lake (HM244209).

Sequences of ANME-2d 16S rRNA gene fragments from DNA of the surface layer of the methane seep PB ( $8 \%$ of all analyzed ANME-2d sequences), layer with oligonite $(140-146 \mathrm{~cm})$ of the mud volcano $\mathrm{M}$ and $82 \%$ of the sequences from $10 \mathrm{~cm}$ sediment layer of the methane seep PB (OTUs 14 and 32) formed a cluster, having a $100 \%$ similarity whether with the sequences from the coal-rich sediments (KJ424521), or freshwater iron-enriched microbial mat (AB722188), as well as Lake Ørn sediments [24].

In the phylogenetic tree, the ANME-2d 16S rRNA gene sequences from all analyzed DNA samples of the mud volcano $\mathrm{M}$ formed a cluster (OTU12) and had a $99-100 \%$ similarity with the sequences that were previously found in the sediments of Chaohu Lake [19] and those of Lake Baikal [63,73].

The molecular analysis did not reveal of typical for marine environment methane-oxidizing archaea ANME1, 2, or 3 in samples of investigated sediments (Figure 4). 


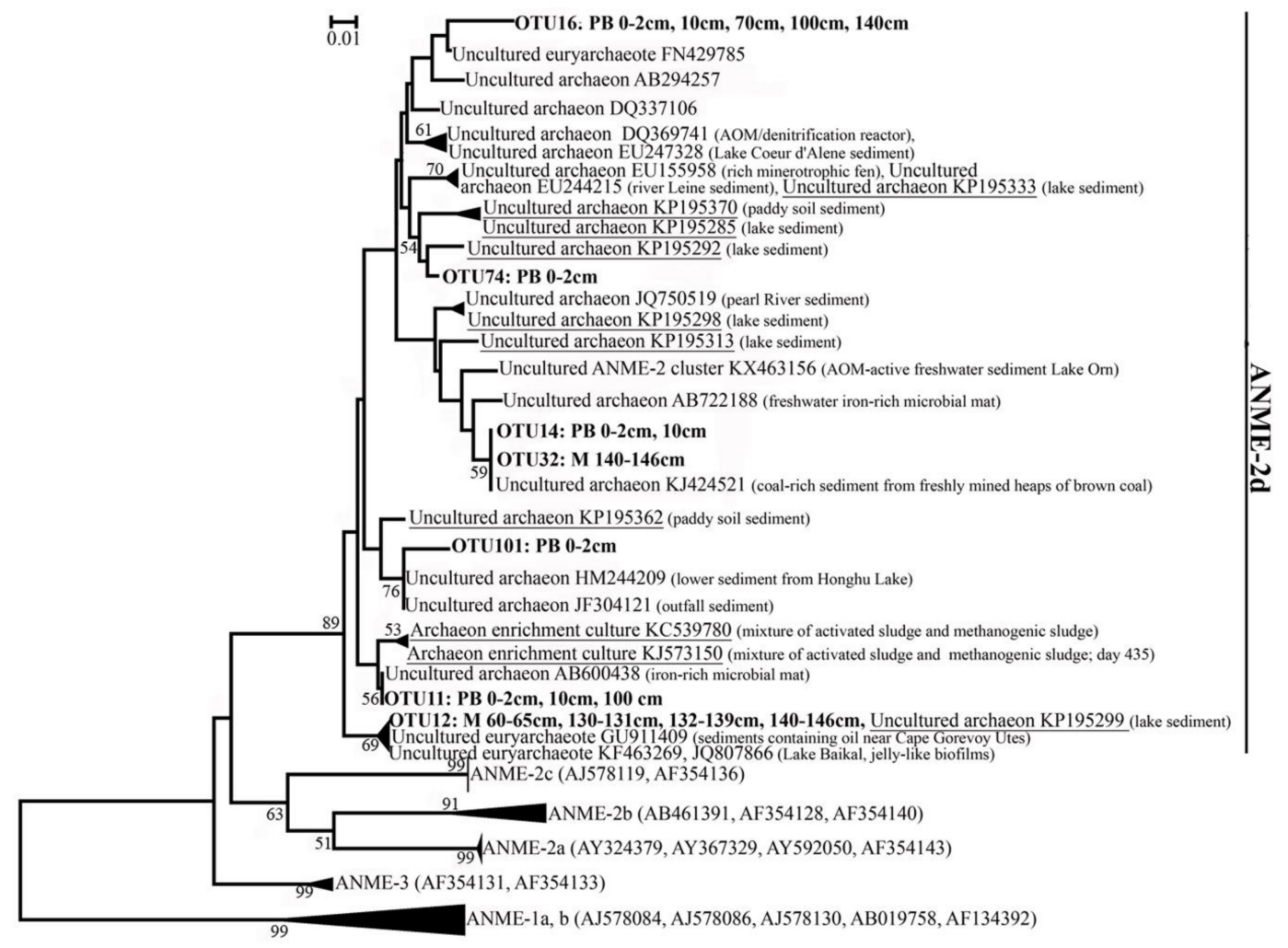

Figure 4. Maximum likelihood phylogenetic tree with the affiliations of the 16S rRNA genes of $M$. nitroreducens-like archaea recovered from deep sediments of the mud volcano Malenky $(\mathrm{M})$ and the methane seep Posolsk Bank (PB). Bootstrap values $>50 \%$ (out of 100 replicates) are shown in front of respective nodes, and the scale bar represents $1 \%$ sequence divergence.

\subsection{Diversity of morA Genes of ANME-2d Sequences in Clone Libraries}

We tested all recovered DNA samples for mcrA genes of the ANME-2d subcluster for each of the recovered $m c r A$ gene libraries. The number of OTUs was from 1 to 2 per sample. The analysis of the obtained translated amino acid sequences has confirmed the presence of $m c r A$ genes of the ANME-2d in the communities. The analyzed amino acid sequences of the bottom sediments from the two investigated areas were similar to $m c r A$ gene sequences of $M$. nitroreducens. The similarity of the recovered nucleotide sequences with those available in the NCBI database was $93-98 \%$ and amino acid sequences (97-100\%). In the phylogenetic tree, the obtained sequences of $m c r A$ gene fragments formed two clusters (Figure 5). The phylotype ANME-2d.mcrA-OTU1 dominated in the number of the recovered sequences. This phylotype included amino acid sequences from different sediments (Figure 5) of the methane seep PB and the mud volcano $\mathrm{M}$ and clustered with the M. nitroreducens sequences from the bioreactor (AQM52588) and rice soils (AQM52582) [41]. The phylotype ANME-2d.mcrA-OTU2 formed a cluster only with sequences from deep sediments of $\mathrm{M}$ and from the bioreactor, in which AOM processes occurred together with iron reduction (PWB49621) [49]. The phylotype ANME-2d.mcrA-OTU3 consisted of sequences from the surface sediments of the methane seep PB and the closest relatives from the microbial mat of Hydrate Ridge North, Pacific Ocean (PPA79495). 


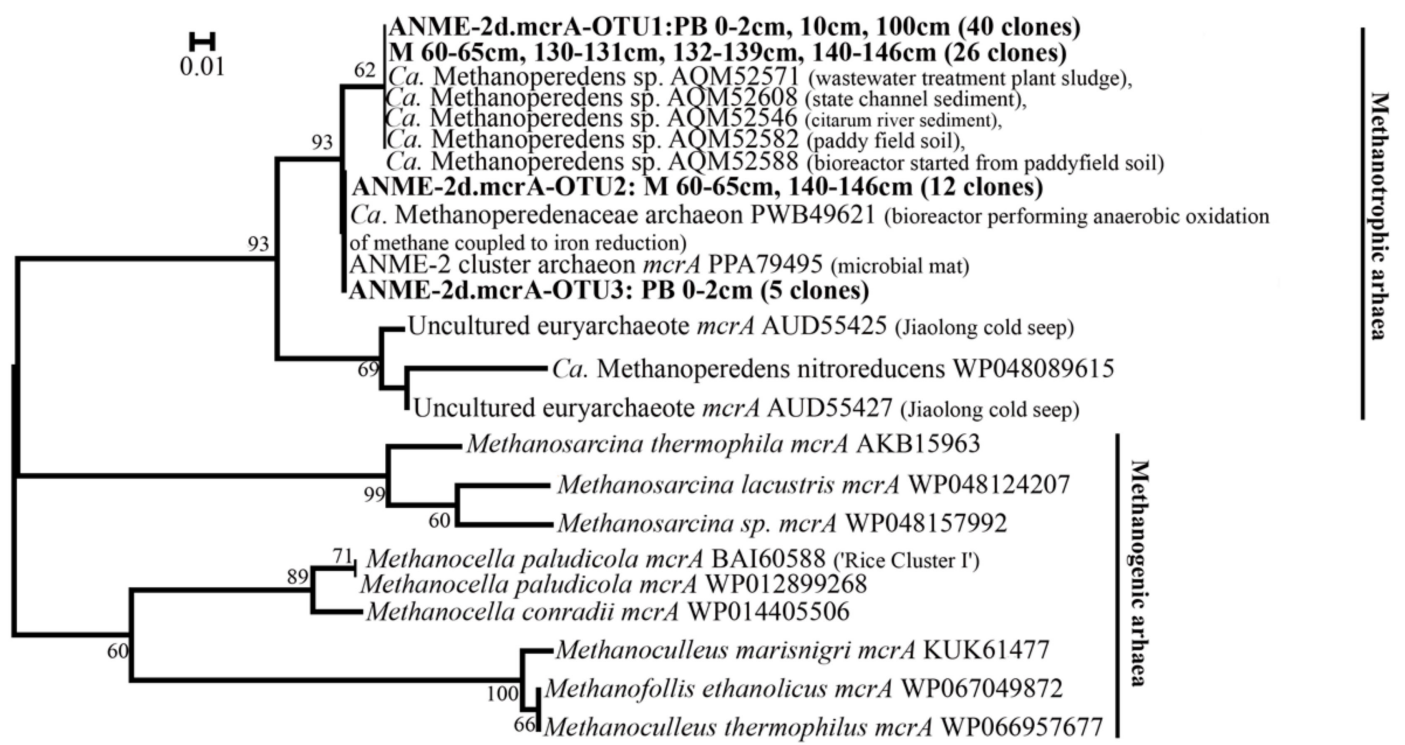

Figure 5. Maximum likelihood phylogenetic tree with the affiliations of the mcrA genes of M. nitroreducens-like archaea recovered from deep sediments the mud volcano Malenky (M) and the methane seep Posolsk Bank (PB). Bootstrap values $>50 \%$ (out of 100 replicates) are shown in front of respective nodes, and the scale bar represents $1 \%$ sequence divergence.

To solidify the absence of representatives typical of marine sediments with methane-oxidizing archaea ANME1, 2, or 3, the DNA samples were tested for mcrA gene of methanogenic and methanotrophic archaea. Specific primers (Table 1) of $m c r A$ gene did not detect members of the above mentioned ANME clusters in investigated DNA samples from deep sediments of Lake Baikal. Phylogenetic analysis indicated that all Baikal sequences of $m c r A$ genes were similar to sequences of the order Methanomicrobiales and Methanosarcinales [60].

\subsection{Diversity of NC10 Bacteria in $16 S$ rRNA Gene Clone Libraries}

We also tested all DNA samples for anaerobic methanotrophs of the phylum NC10. Since the metagenomic analysis with universal bacterial primers [63] did not confirm the presence of the members of this phylum at the investigated sites, we performed an additional PCR analysis with the specific primers for this bacterial phylum (Table 1). These primers detected the NC10 bacteria relative to $M$. oxyfera in all investigated sediments of the mud volcano $\mathrm{M}$ and methane seep PB, in which archaea of the ANME-2d subcluster were previously detected. Phylogenetic analysis showed that the recovered nucleotide sequences were $97-99 \%$ identical to the 16S rRNA gene of M. oxyfera. All recovered nucleotide sequences of 16S rRNA gene sequences of bacteria from the NC10 phylum grouped into four OTUs.

Phylogenetic analysis indicated that dominant phylotypes in the investigated 16S rRNA gene libraries were NC10-1-OTU1, having a 99\% similarity with the uncultured candidate division of the NC10 bacteria (HQ906512, HQ906514) from the sediments of Lake Constance [27], and NC10-2-OTU2 (20 clones), having a 99\% similarity with the uncultured bacteria from the denitrification zone of Lake Biwa (AB661499) [74]. Other phylotypes were minor in the 16S rRNA gene libraries, and they were represented by 5 (NC10-4-OTU4) and 10 (NC10-3-OTU3) clones. The phylotype NC10-3-OTU3 was close, with various similarity (97-99\%), to the uncultured bacteria from the basalt underground ecosystem. The phylotype (NC10-4-OTU4) was close (99\% similarity) to the uncultured Methylomirabilis sp. (JX252156, JX262159) from the enrichment cultures that carry out nitrite-dependent AOM (Figure 6). 


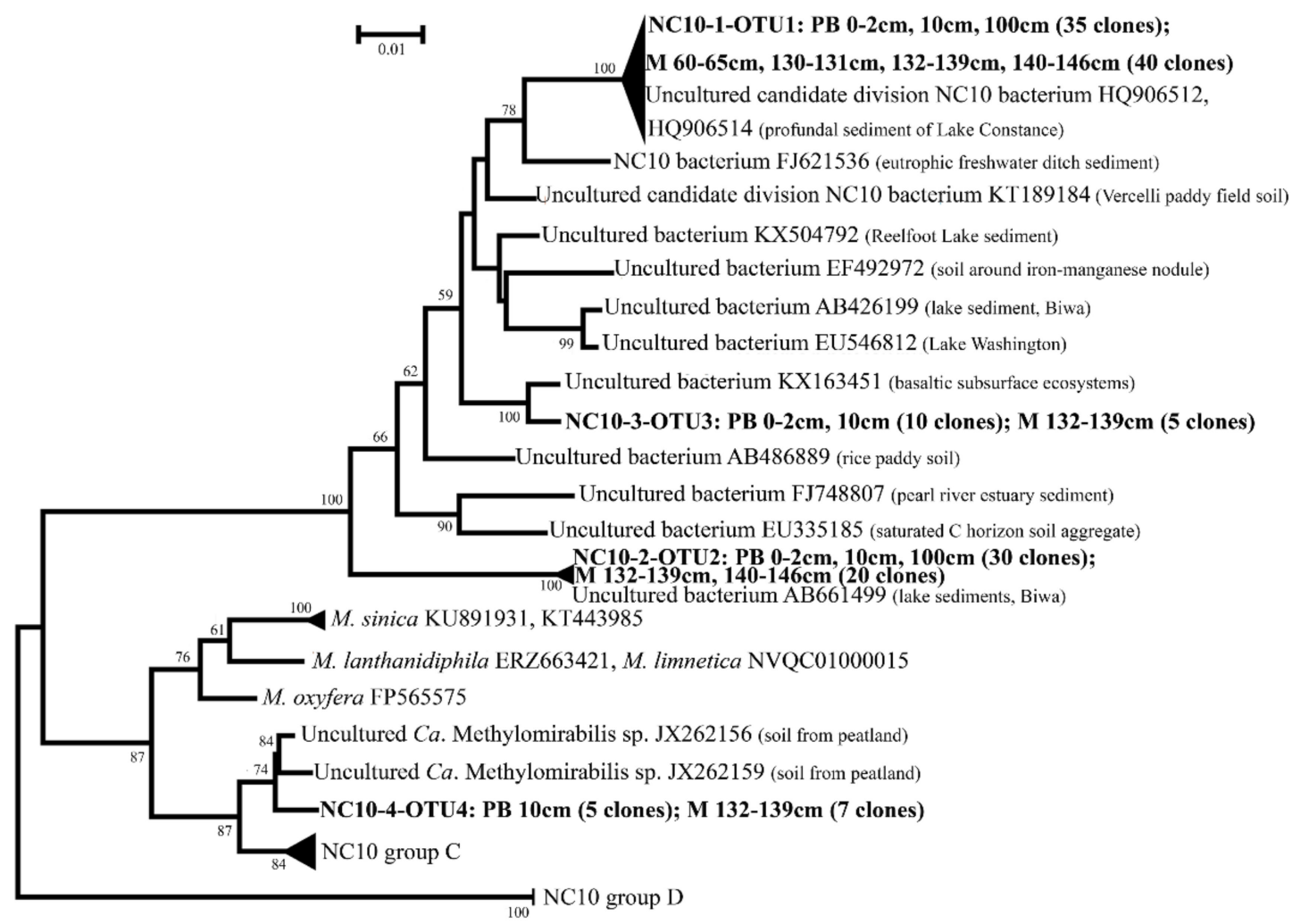

Figure 6. Maximum likelihood phylogenetic tree with the affiliations of the 16S rRNA genes of M. oxyfera-like bacteria recovered from deep sediments the mud volcano Malenky $(\mathrm{M})$ and the methane seep Posolsk Bank (PB). Bootstrap values $>50 \%$ (out of 100 replicates) are shown in front of respective nodes, and the scale bar represents $1 \%$ sequence divergence.

\subsection{Diversity of pmoA Genes of the NC10 Bacteria in Clone Libraries}

The genome of the NC10 bacteria encodes the complete aerobic methane oxidation pathway [21], and the $p m o A$ gene encodes a subunit of particulate methane monooxygenase (pMMO). The $p m o A$ gene can be used as a biological marker to identify the NC10 bacteria $[25,75]$. PCR analysis of the investigated samples of bottom sediments successfully detected specific $p m o A$ gene sequences of the NC10 bacteria using primers targeting $p m o A$ gene (Table 1). All reserved amino acid sequences of pmoA bacterial genes of the phylum NC10 grouped into three OTUs. The bulk of the pmoA gene sequences (NC10.pmoA-OTU1), which were recovered from the samples, were the most similar to Methylomirabilis sp. (94-98\%) from the soil and the uncultured NC10 bacteria of the Lake Biwa sediments (BAL70515) and water in dam reservoir (BAP16645). Whereas one-third of the pmoA gene sequences (NC10.pmoA-OTU2) were similar to NC10 bacteria (90-95\%) from wastewater treatment plant Lieshout (AEJ33959) (Figure 7), pmoA sequences (NC10.pmoA-OTU3) from both the methane seep and the mud volcano again clustered together with $p m o A$ sequences from the Lake Constance sediments (ADY76950) and M. limnetica (WP107560874). 


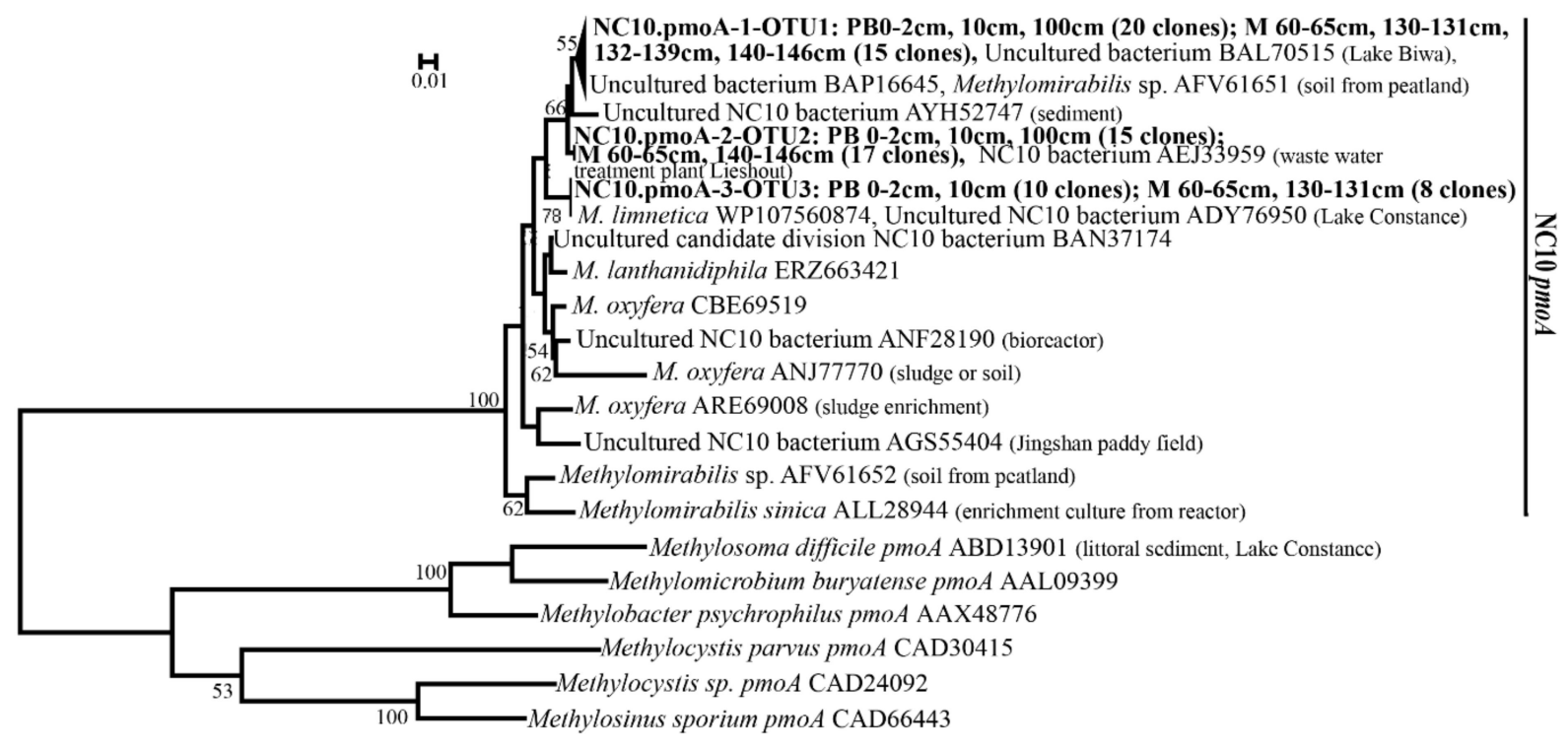

Figure 7. Maximum likelihood phylogenetic tree with the affiliations of the pmoA genes of M. oxyfera-like bacteria recovered from deep sediments the mud volcano Malenky $(\mathrm{M})$ and the methane seep Posolsk Bank (PB). Bootstrap values $>50 \%$ (out of 100 replicates) are shown in front of respective nodes, and the scale bar represents $1 \%$ sequence divergence.

\section{Discussion}

Analysis of different genes has confirmed the presence of archaea and bacteria that most likely carry out AOM processes in sediments of various geological structures in Lake Baikal (methane seep and mud volcano), which are different in the composition of the discharged fluid and contained CHs. In sediment layers that contained GHs concentrations of all analyzed ions were two to three times higher compared to reference values [66]. The abnormally high values of some ions in such zones are due to the displacement of salts from the water during GH formation, which was repeatedly indicated at other sites with the near-surface occurrence of GHs [63]. In addition to GHs, bottom sediments of the mud volcano $\mathrm{M}$ contained carbonate, presence of which in GH-bearing sediments of mud volcanoes was previously indicated [76]. Methane concentrations in the sediments at the investigated sites increase with depth, reaching the maximum values, and the obtained profiles of methane distribution curves are similar to those in the AOM zones of other freshwater ecosystems [24,58].

The structure of microbial communities was previously studied in deep sediments of methane seeps and mud volcanoes in Lake Baikal. However, no marine uncultivated anaerobic methanotrophic archaea of the ANME clusters were found either in surface sediments or zones of GH occurrence [57,59,60,68,73]. The absence of ANME clusters that are typical for marine ecosystems is understandable since in deep sediments of some gas-saturated areas (oil seeps and methane seeps), the concentration of sulfate ions is comparable with the reference values (up to $82 \mu \mathrm{M}$ ) [55,56], which is insufficient for the occurrence of geochemically significant sulfate-dependent AOM. This is also consistent with the studies which indicate sulfate-dependent $\mathrm{AOM}$ as the main process for methane removal in marine environments where the concentrations of sulfate ions reach $28,000 \mu \mathrm{M}$ [16]. In the investigated sediments of the mud volcano $\mathrm{M}$, we observed relatively high concentrations of sulfate ions (up to $3781 \mu \mathrm{M}$ ) compared to other freshwater lakes (from 20 to $300 \mu \mathrm{M}$ ) [27,58,77]. Similar concentrations of sulfate ions in Baikal (up to $2000 \mu \mathrm{M}$ ) were observed in the sediments of freshwater Lake Cadagno, though, like in Lake Baikal, the members of the marine ANME clusters were also not detected there [58]. To carry out $\mathrm{AOM}$, the marine ANME clusters require the presence of sulfate-reducing bacteria. According to the high-throughput sequencing data, their proportion does not exceed $2 \%$ of all analyzed $16 \mathrm{~S}$ rRNA bacterial sequences in investigation deep sediments of the mud volcano $\mathrm{M}$ and the methane seep PB [63]. Rates of sulfate reduction in the sediments of site Lake Baikal varied from 0.001 to 
$0.07 \mathrm{nM} /$ day $[57,78]$. There was a greater variety of sulfate-reducing bacteria and a high rate of sulfate reduction in the bottom sediments of the methane seep PB. Sulfate-reducing bacteria from this site accounted for $9.2-9.5 \%$ of all analyzed $16 \mathrm{~S}$ rRNA gene sequences [59], among which members of the genus Desulfosporosinus were detected by molecular methods [55]. The range of sulfate-reduction rates was $1.2 \mathrm{nM}$ in the sediments below $60 \mathrm{~cm}$ and $1000 \mathrm{nM}$ in the surface layer $(0-2 \mathrm{~cm})$. The obvious activity of sulfate-reducing bacteria remained up to a depth of $40-50 \mathrm{~cm}$ where there was a high methane concentration [55]. Constant fluid flow from deep sediments enriched, in particular, with sulfate ions ensure the presence of sulfate-reducing microorganisms in the studied communities [59]. As far as sulfate content is mostly very low and no ANME1, 2, 3 known for coupling AOM to sulfate reduction sequences were detected, it is possible that other mechanisms of AOM are functioning.

In contrast to the ANME clusters, members NC10 bacteria and ANME-2d archaea do not need a partner to carry out AOM and are widespread in freshwater ecosystems [22,23,33-35]. However, in the investigated sediments of Lake Baikal, there were no nitrate and nitrite ions in case of the mud volcano $\mathrm{M}$, or they were present in the surface sediments of the methane seep PB. Lack of these ions, which are necessary for AOM, in the Baikal sediments can be due to their rapid involvement in methane oxidation, owing to the members of the ANME-2d subcluster and bacteria of the phylum NC10. Perhaps lack of nitrate and nitrite ions, being electron acceptors for AOM, in the sediments of Lake Baikal can be compensated, owing to the activity of archaea of the phylum Thaumarchaeota $[79,80]$. Ammonium-oxidizing members of this phylum at the investigated sites of Lake Baikal comprised a significant part of all analyzed archaea: up to $40 \%$ near the methane seep PB [59] and 20\% near the mud volcano M [60].

Our study has shown that sequences of the ANME-2d have different numbers of OTUs and diverse composition near the methane seep and the mud volcano. The most diverse sequences, which were included into five OTUs, we have recovered for the surface layer of the methane seep PB. At the same time, we have not detected the representatives of the nitrate-dependent AOM in two deep GH-containing sediments from this site $(70$ and $140 \mathrm{~cm})$. The absence of the ANME-2d representatives in deep sediments and their wide variety in the surface sediments most likely result from the influence of convective mineralized fluids, which circulate in the GH stability zone [81,82]. Their constant flow may also be responsible for development of methanotrophic archaea in the surface sediments, ensuring reducing conditions of the environment and influx of the carbon sources and energy as well as their lack in deep anaerobic zones [59]. If the fluid circulation indeed takes place in the sedimentary stratum up to a depth of $400 \mathrm{~m}$ in the communities of surface sedimentary layers, there may be representatives of deep microorganisms together with cosmopolitan prokaryotes. Sediments of the methane seep M have 1-2 OTU sequences of the ANME-2d 16S rRNA gene fragments. According to the phylogenetic analysis, the recovered sequences of the ANME-2d representatives are similar to those from the river, lake and freshwater sediments as well as soils of rice fields and enrichment cultures of denitrifying methanotrophs $[19,23,24,83]$. In the investigated sediments, we have indicated the presence of the archaeal $m c r A$ genes of the ANME-2d subcluster using the additional PCR analysis and recently developed primers [41]. Since the general mcrA primer pair ME1F/ME2R [37] did not detect $m c r A$ sequences of ANME-2d [60]; further still, the presence of these microorganisms and their diversity in environmental studies may be underestimated, as presently used primers simply do not capture them. Phylogenetic analysis has revealed that $m c r A$ gene sequences from the areas of the methane seep PB and mud volcano M clustered together with available $m c r A$ sequences of the known M. nitroreducens-like archaea from freshwater habitats and bioreactor, starting from paddy field soil, the Citarum River sediments and microbial mat [41].

In bioreactors, the representatives of ANME-2d, NC10, and ANAMMOX bacteria can coexist and compete with each other for the availability of nitrate and nitrite ions, which can lead to the simultaneous conversion of ammonium, methane, and nitrogen oxides to harmless $\mathrm{N}_{2}$ and $\mathrm{CO}_{2}$ [44]. Both ANAMMOX bacteria and $\mathrm{NC} 10$ bacteria grow in anoxic conditions and use $\mathrm{NO}_{2}{ }^{-}$ions as terminal electron acceptor. Ions of $\mathrm{NO}_{3}{ }^{-}, \mathrm{NO}_{2}{ }^{-}, \mathrm{NH}_{4}{ }^{-}$, and methane often coexist in the anoxic conditions of 
different freshwater ecosystems. It is assumed that wetlands may be a suitable environment for the coexistence of these two taxonomic groups of bacteria, despite their competition for $\mathrm{NO}_{2}{ }^{-}$as an electron acceptor for ANAMMOX or AOM processes, respectively [80]. Using molecular methods, showed that ANAMMOX bacteria and NC10 bacteria coexist in paddy soil and saline lake sediments $[84,85]$. For this reason, in this study, we have searched for representatives of candidate phylum of the NC10 bacteria in the sediments of the methane seep PB and the mud volcano M. In all investigated sediments with ANME-2d archaea, we detected the representatives of the phylum NC10. We did not find them at depths of 70 and $140 \mathrm{~cm}$ near the methane seep $\mathrm{PB}$, which also confirms a possible coexistence of these microorganisms. The NC10 bacteria carry out AOM in the presence of $\mathrm{NO}_{2}{ }^{-}$ions in the environment, which were not found in pore waters of the investigated sites, or their concentrations were lower than the values of nitrate ions in the sediments. Lower nitrite values compared to nitrate ions can be due to the likely toxicity of nitrite in a concentration of $1.5 \mu \mathrm{M}$ for the NC10 bacteria [79]. From the investigated sites, we have recovered four OTUs that belong to the candidate phylum NC10. The sequences of the NC10 phylum close to the Baikal ones were previously found in the sediments of Lake Constance [27], rice soils [86], and eutrophic lakes [87]. Moreover, in the investigated samples, we have confirmed the presence of the functional pmoA genes, which can serve as a biological marker for the identification of the NC10 bacteria. The pmoA gene sequences, which were recovered from the sediments of Lake Baikal, are similar in amino acid and nucleotide sequences with those from Lake Biwa [74], Lake Constance [27], as well as with Methylomirabilis sp. and M. limnetica.

We also hypothesize that iron ions can serve as electron acceptors during AOM in the sediments of Lake Baikal. Regardless of the location of the investigated sites, the chemical composition of pore waters and discharged fluid, all sediments had high concentrations of iron ions $\left(\mathrm{Fe}^{2+}\right)$ : up to $134 \mu \mathrm{M}$ in deep sediments and up to $52.5 \mu \mathrm{M}$ in the surface sediments compared to the reference sites at Lake Baikal. Iron is present in freshwater bodies that are depleted of sulfate and nitrate and where methane is oxidized in anaerobic zone [20,46-48,88]. It is also proposed that Fe(III)-dependent AOM was largely responsible for oxidizing the entirety of methane produced on early Earth prior to the advent of oxygen [45]. This process can potentially occur by $M$. nitroreducens [22,44]. They are also universal anaerobic methanotrophs that can use various oxidizers as electron acceptors (iron or nitrate ions), like pore waters of Lake Baikal, which vary in chemical composition, and, thus, may play an important role in controlling methane freshwater systems [89].

Our study confirms the presence of the NC10 bacteria and ANME-2d archaea based on the analysis of 16S rRNA gene sequences and functional genes ( $p m o A$ and $m c r A$ ) of AOM with concentrations of nitrite and nitrate ions below $20 \mu \mathrm{M}$ in freshwater sediments. We also show that recently discovered AOM process together with denitrification can occur in Lake Baikal in the absence of representatives of the ANME clusters, which are responsible for AOM in marine sediments. However, we think it could be plausible that the microorganisms that have been obtained in this study can $\mathrm{use} \mathrm{Fe}^{3+}$ and $\mathrm{SO}_{4}{ }^{2-}$ as electron acceptors to oxidize methane in the sediments of Lake Baikal.

Author Contributions: Conceptualization, T.Z. and A.L.; Sample collection, A.L.; Chemical analysis, T.P.; Measurements of methane concentrations, G.K.; Molecular analyses, S.C. and A.L.; Writing-Original draft preparation, T.Z. and A.L.; Writing-Review and editing, T.Z. and A.L. All authors have read and agreed to the published version of the manuscript.

Funding: This work was carried out within the framework of the State Assignment no. 0345-2019-0007 (expedition studies) and was supported by the Russian Foundation for Basic Research, project no. 18-04-00244_a (molecular and chemical studies).

Conflicts of Interest: The authors declare no conflict of interest.

\section{References}

1. Kortelainen, P.; Pajunen, H.; Rantakari, M.; Saarnisto, M. A Large carbon pool and small sink in boreal holocene lake sediments. Glob. Chang. Biol. 2004, 10, 1648-1653. [CrossRef] 
2. Molot, L.A.; Dillon, P.J. Storage of terrestrial carbon in boreal lake sediments and evasion to the stmosphere. Glob. Biogeochem. Cycles 1996, 10, 483-492. [CrossRef]

3. Bastviken, D.; Cole, J.; Pace, M.; Tranvik, L. Methane Emissions from Lakes: Dependence of Lake characteristics, two regional assessments, and a global estimate. Glob. Biogeochem. Cycles 2004, 18, GB4009. [CrossRef]

4. Chistoserdova, L. Methylotrophs in natural habitats: Current insights through metagenomics. Appl. Microbiol. Biotechnol. 2015, 99, 5763-5779. [CrossRef]

5. Dedysh, S.N.; Derakshani, M.; Liesack, W. Detection and enumeration of methanotrophs in acidic Sphagnum peat by $16 \mathrm{~S}$ rRNA fuorescence in situ hybridization, including the use of newly developed oligonucleotide probes for Methylocella palustris. Appl. Environ. Microbiol. 2001, 67, 4850-4857. [CrossRef]

6. Gal'chemko, V.F. Methanotrophic Bacteria; GEOS: Moscow, Russia, 2001; p. 500.

7. Hanson, R.S.; Hanson, T.E. Methanotrophic bacteria. Microbiol. Rev. 1996, 60, 439-471.

8. Kallistova, A.Y.; Goel, G.; Nozhevnikova, A.N. Microbial diversity of methanogenic communities in the systems for anaerobic treatment of organic waste. Microbiology 2014, 83, 462-483. (In Russian) [CrossRef]

9. Pimenov, N.V.; Kallistova, A.Y.; Rusanov, I.I.; Yusupov, S.K.; Montonen, L.; Jurgens, G.; Münster, U.; Nozhevnikova, A.N.; Ivanov, M.V. Methane formation and oxidation in the meromictic oligotrophic Lake Gek-Gel (Azerbaijan). Microbiology 2010, 79, 247-252. (In Russian) [CrossRef]

10. Op den Camp, H.J.M.; Islam, T.; Stott, M.B.; Harhangi, H.R.; Hynes, A.; Schouten, S.; Jetten, M.S.M.; Birkeland, N.K.; Pol, A.; Dunfield, P.F. Environmental, genomic and taxonomic perspectives on methanotrophic Verrucomicrobia. Environ. Microbiol. Rep. 2009, 1, 293-306. [CrossRef]

11. Boetius, A.; Ravenschlag, K.; Schubert, C.; Rickert, D.; Widdel, F.; Gieseke, A.; Amann, R.; Jørgensen, B.B.; Witte, U.; Pfannkuche, O. A marine microbial consortium apparently mediating anaerobic oxidation of methane. Nature 2000, 407, 623-626. [CrossRef]

12. Hoehler, T.M.; Alperin, M.J.; Albert, D.B.; Martens, C.S. Field and laboratory studies of methane oxidation in an anoxic marine sediment: Evidence for a methanogen-sulfate reducer consortium. Glob. Biogeochem. Cycles 1994, 8, 451-463. [CrossRef]

13. Reeburgh, W.S. Methane consumption in Cariaco trench waters and sediments. Earth Planet. Sci. Lett. 1976, 28, 337-344. [CrossRef]

14. Valentine, D.L.; Reeburgh, W.S. New perspectives on anaerobic methane oxidation. Environ. Microbiol. 2000, 2, 477-484. [CrossRef] [PubMed]

15. Knittel, K.; Losekann, T.; Boetius, A.; Kort, R.; Amann, R. Diversity and distribution of methanotrophic archaea at cold seeps. Appl. Environ. Microbiol. 2005, 71, 467-479. [CrossRef]

16. Knittel, K.; Boetius, A. Anaerobic oxidation of methane: Progress with an unknown process. Annu. Rev. Microbiol. 2009, 63, 311-334. [CrossRef]

17. Nauhaus, K.; Boetius, A.; Kruger, M.; Widdel, F. In vitro demonstration of anaerobic oxidation of methane coupled to sulphate reduction in sediment from a marine gas hydrate area. Environ. Microbiol. 2002, 4, 296-305. [CrossRef]

18. Hinrichs, K.; Boetius, A. The anaerobic oxidation of methane: New insights in microbial ecology and biogeochemistry. In Ocean margin systems; Springer: Berlin, Germany, 2002; pp. 457-477.

19. Ding, J.; Ding, Z.W.; Fu, L.; Lu, Y.Z.; Cheng, S.H.; Zeng, R.J. New primers for detecting and quantifying denitrifying anaerobic methane oxidation archaea in different ecological niches. Appl. Microbiol. Biotechnol. 2015, 99, 9805-9812. [CrossRef]

20. Egger, M.; Rasigraf, O.; Sapart, C.J.; Jilbert, T.; Jetten, M.S.; Rockmann, T.; van der Veen, C.; Banda, N.; Kartal, B.; Ettwig, K.; et al. Iron-mediated anaerobic oxidation of methane in brackish coastal sediments. Environ. Sci. Technol. 2015, 49, 277-283. [CrossRef]

21. Ettwig, K.F.; Butler, M.K.; Le Paslier, D.; Pelletier, E.; Mangenot, S.; Kuypers, M.M.; Schreiber, F.; Dutilh, B.E.; Zedelius, J.; de Beer, D.; et al. Nitrite-driven anaerobic methane oxidation by oxygenic bacteria. Nature 2010, 464, 543-548. [CrossRef]

22. Haroon, M.F.; Hu, S.; Shi, Y.; Imelfort, M.; Keller, J.; Hugenholtz, P.; Yuan, Z.; Tyson, G.W. Anaerobic oxidation of methane coupled to nitrate reduction in a novel archaeal lineage. Nature 2013, 500, 567-570. [CrossRef]

23. Raghoebarsing, A.A.; Pol, A.; van de Pas-Schoonen, K.T.; Smolders, A.J.; Ettwig, K.F.; Rijpstra, W.I.; Schouten, S.; Damste, J.S.; Op den Camp, H.J.; Jetten, M.S.; et al. A Microbial consortium couples anaerobic methane oxidation to denitrification. Nature 2006, 440, 918-921. [CrossRef] [PubMed] 
24. Weber, H.S.; Habicht, K.S.; Thamdrup, B. Anaerobic methanotrophic archaea of the ANME-2d cluster are active in a low-sulfate, iron-rich freshwater sediment. Front. Microbiol. 2017, 8, 619. [CrossRef] [PubMed]

25. Luesken, F.A.; Zhu, B.; van Alen, T.A.; Butler, M.K.; Diaz, M.R.; Song, B.; Op den Camp, H.J.; Jetten, M.S.; Ettwig, K.F. pmoA primers for detection of anaerobic methanotrophs. Appl. Environ. Microbiol. 2011, 77, 3877-3880. [CrossRef] [PubMed]

26. Zhu, B.; Wang, J.; Bradford, L.M.; Ettwig, K.; Hu, B.; Lueders, T. Nitric oxide dismutase (nod) genes as a functional marker for the diversity and phylogeny of methane-driven oxygenic denitrifiers. Front. Microbiol. 2019, 10, 1577. [CrossRef] [PubMed]

27. Deutzmann, J.S.; Schink, B. Anaerobic Oxidation of Methane in Sediments of Lake Constance, an Oligotrophic Freshwater Lake. Appl. Environ. Microbiol. 2011, 77, 4429-4436. [CrossRef] [PubMed]

28. Hu, B.L.; Shen, L.D.; Lian, X.; Zhu, Q.; Liu, S.; Huang, Q.; He, Z.F.; Geng, S.; Cheng, D.Q.; Lou, L.P.; et al. Evidence for nitrite-dependent anaerobic methane oxidation as a previously overlooked microbial methane sink in wetlands. Proc. Natl. Acad. Sci. USA 2014, 111, 4495-4500. [CrossRef]

29. Zhou, L.; Wang, Y.; Long, X.E.; Guo, J.; Zhu, G. High abundance and diversity of nitrite-dependent anaerobic methane-oxidizing bacteria in a paddy field profile. FEMS Microbiol. Lett. 2014, 360, 33-41. [CrossRef]

30. Zhu, B.; van Dijk, G.; Fritz, C.; Smolders, A.J.; Pol, A.; Jetten, M.S.; Ettwig, K.F. Anaerobic oxidization of methane in a minerotrophic peatland: Enrichment of nitrite-dependent methane-oxidizing bacteria. Appl. Environ. Microbiol. 2012, 78, 8657-8665. [CrossRef]

31. Zhu, B.; Bradford, L.; Huang, S.; Szalay, A.; Leix, C.; Weissbach, M.; Táncsics, A.; Drewes, J.E.; Lueders, T. Unexpected diversity and high abundance of putative nitric oxide dismutase (nod) genes in contaminated aquifers and wastewater treatment systems. Appl. Environ. Microbiol. 2017, 4, 02750-16. [CrossRef]

32. Lu, Y.-Z.; Liang, F.; Li, N.; Ding, J.; Bai, Y.-N.; Samaras, P.; Zeng, R.J. The content of trace element iron is a key factor for competition between anaerobic ammonium oxidation and methane-dependent denitrification processes. Chemosphere 2018, 198, 370-376. [CrossRef]

33. Fu, L.; Li, S.W.; Ding, Z.W.; Ding, J.; Lu, Y.Z.; Zeng, R.J. Iron reduction in the DAMO/Shewanella oneidensis MR-1 coculture system and the fate of Fe(II). Water Res. 2016, 88, 808-815. [CrossRef] [PubMed]

34. Timmers, P.H.; Welte, C.U.; Koehorst, J.J.; Plugge, C.M.; Jetten, M.S.; Stams, A.J. Reverse methanogenesis and respiration in methanotrophic archaea. Archaea 2017, 2017, 1654237. [CrossRef] [PubMed]

35. Welte, C.U.; Rasigraf, O.; Vaksmaa, A.; Versantvoort, W.; Arshad, A.; Op den Camp, H.J.; Jetten, M.S.; Lüke, C.; Reimann, J. Nitrate- and nitrite-dependent anaerobic oxidation of methane. Environ. Microbiol. Rep. 2016, 8, 941. [CrossRef] [PubMed]

36. Arshad, A.; Speth, D.R.; De Graaf, R.M.; Op den Camp,H.J.M.; Jetten, M.S.; Welte, C.U. A metagenomics-based metabolic model of nitrate-dependent anaerobic oxidation of methane by Methanoperedens-like archaea. Front. Microbiol. 2015, 6, 1423. [CrossRef]

37. Hales, B.A.; Edwards, C.; Ritchie, D.A.; Hall, G.; Pickup, R.W.; Saunders, J.R. Isolation and identification of methanogen-specific DNA from blanket bog feat by PCR amplification and sequence analysis. Appl. Environ. Microbiol. 1996, 62, 668-675.

38. Juottonen, H.; Galand, P.E.; Yrjala, K. Detection of Methanogenic Archaea in Peat: Comparison of PCR primers targeting the morA gene. Res. Microbiol. 2006, 157, 914-921. [CrossRef]

39. Luton, P.E.; Wayne, J.M.; Sharp, R.J.; Riley, P.W. The mcrA gene as an alternative to $16 \mathrm{~S}$ rRNA in the phylogenetic analysis of methanogen populations in landfill. Microbiology 2002, 148, 3521-3530. [CrossRef]

40. Nunoura, T.; Oida, H.; Miyazaki, J.; Miyashita, A.; Imachi, H.; Takai, K. Quantification of mcrA by fluorescent PCR in methanogenic and methanotrophic microbial communities. FEMS Microbiol. Ecol. 2008, 64, 240-247. [CrossRef]

41. Vaksmaa, A.; Guerrero-Cruz, S.; van Alen, T.A.; Cremers, G.; Ettwig, K.F.; Luke, C.; Jetten, M.S.M. Enrichment of anaerobic nitrate-dependent methanotrophic "Candidatus Methanoperedens nitroreducens" archaea from an italian paddy field soil. Appl. Microbiol. Biotechnol. 2017, 101, 7075-7084. [CrossRef]

42. Evans, P.N.; Parks, D.H.; Chadwick, G.L.; Robbins, S.J.; Orphan, V.J.; Golding, S.D.; Tyson, G.V. Methane metabolism in the archaeal phylum Bathyarchaeota revealed by genome-centric metagenomics. Science 2015, 350, 434-438. [CrossRef]

43. Vanwonterghem, I.; Evans, P.N.; Parks, D.H.; Jensen, P.D.; Woodcroft, B.J.; Hugenholtz, P.; Hugenholtz, G.V. Methylotrophic methanogenesis discovered in the archaeal phylum Verstraetearchaeota. Nat. Microbiol. 2016, 1, 16170. [CrossRef] [PubMed] 
44. Ettwig, K.F.; Zhu, B.; Speth, D.; Keltjens, J.T.; Jetten, M.S.M.; Kartal, B. Archaea Catalyze iron-dependent anaerobic oxidation of methane. Proc. Natl. Acad. Sci. USA 2016, 113, 12792-12796. [CrossRef] [PubMed]

45. Beal, E.J.; House, C.H.; Orphan, V.J. Manganese- and iron-dependent marine methane oxidation. Science 2009, 325, 184-187. [CrossRef] [PubMed]

46. Sivan, O.; Adler, M.; Pearson, A.; Gelman, F.; Bar-Or, I.; John, S.G.; Eckert, W. Geochemical evidence for iron-mediated anaerobic oxidation of methane. Limnol. Oceanogr. 2011, 56, 1536-1544. [CrossRef]

47. Norði, K.A.; Thamdrup, B.; Schubert, C.J. Anaerobic oxidation of methane in an iron-rich danish freshwater lake sediment. Limnol. Oceanogr. 2013, 58, 546-554. [CrossRef]

48. Savvichev, A.S.; Kokryatskaya, N.M.; Zabelina, S.A.; Rusanov, I.I.; Zakharova, E.E.; Veslopolova, E.F.; Lunina, O.N.; Patutina, E.O.; Bumazhkin, B.K.; Gruzdev, D.S.; et al. Microbial Processes of the carbon and sulfur cycles in an ice-covered, iron-rich neromictic Lake Svetloe (Arkhangelsk Region, Russia). Environ. Microbiol. 2017, 19, 659-672. [CrossRef]

49. Cai, C.; Leu, A.O.; Xie, G.J.; Guo, J.; Feng, Y.; Zhao, J.X.; Tyson, G.W.; Yuan, Z.; Hu, S. A methanotrophic archaeon couples anaerobic oxidation of methane to Fe(III) reduction. ISME J. 2018, 12, 1929-1939. [CrossRef]

50. Weber, H.S.; Thamdrup, B.; Habicht, K.S. High sulfur isotope fractionation associated with anaerobic oxidation of methane in a low sulfate, iron-rich environment. Front. Earth Sci. 2016, 4, 61. [CrossRef]

51. Khlystov, O.M.; Khabuev, A.V.; Minami, H.; Hachikubo, A.; Krylov, A.A. Gas hydrates in Lake Baikal. LFWB 2018, 1, 66-70. (In Russian) [CrossRef]

52. Khlystov, O.M.; Poort, J.; Mazzini, A.; Akhmanov, G.G.; Minami, H.; Hachikubo, A.; Khabuev, A.V.; Kazakov, A.V.; De Batist, M.; Naudts, L.; et al. Shallow-rooted mud volcanism in Lake Baikal. Mar. Pet. Geol. 2019, 102, 580-589. [CrossRef]

53. Dagurova, O.P.; Namsaraev, B.B.; Kozyreva, L.P.; Zemskaya, T.I.; Dulov, L.E. Bacterial processes of the methane cycle in bottom sediments of Lake Baikal. Microbiology 2004, 73, 202-210. (In Russian) [CrossRef]

54. Edgar, R.C.; Haas, B.J.; Clemente, J.C.; Quince, C.; Knight, R. UCHIME improves sensitivity and speed of chimera detection. Bioinformatics 2010, 27, 2194-2200. [CrossRef] [PubMed]

55. Pimenov, N.V.; Zakharova, E.E.; Bryukhanov, A.L.; Korneeva, V.A.; Kuznetsov, B.B.; Tourova, T.P.; Pogodaeva, T.V.; Kalmychkov, G.V.; Zemskaya, T.I. Activity and structure of the sulfate-reducing bacterial community in the sediments of the Southern Part of Lake Baikal. Microbiology 2014, 83, 47-55. (In Russian) [CrossRef]

56. Zemskaya, T.I.; Khlystov, O.M.; Egorov, A.V.; Pogodaeva, T.V.; Kalmychkov, G.V.; Shubenkova, O.V.; Chernitsyna, S.M.; Vorob'eva, S.S.; Grachev, M.A. Integrated Studies of Gas Hydrate Manifestations in the Sediments of Lake Baikal Mud Volcanoes. In Processes in the Boisphere: Changes in Soil and Plant Cover and RF Territorial Waters, Matter Turnover Caused by Global Climatic Changes and Catastrophic Processes; Zavarzin, G.A., Kudeyarov, V.N., Eds.; Pushchino: Moscow, Russia, 2008; Chapter 4; pp. 125-152.

57. Zemskaya, T.I.; Pogodaeva, T.V.; Shubenkova, O.V.; Chernitsina, S.M.; Dagurova, O.P.; Buryukhaev, S.P.; Namsaraev, B.B.; Khlystov, O.M.; Egorov, A.V.; Krylov, A.A.; et al. Geochemical and microbiological characteristics of sediments near the Malenky Mud Volcano (Lake Baikal, Russia), with evidence of archaea intermediate between the marine anaerobic methanotrophs ANME-2 and ANME-3. Geo Mar. Lett. 2010, 30, 411-425.

58. Schubert, C.J.; Vazquez, F.; Lösekann-Behrens, T.; Knittel, K.; Tonolla, M.; Boetius, A. Evidence for anaerobic oxidation of methane in sediments of a freshwater system (Lago di Cadagno). FEMS Microbiol. Ecol. 2011, 76, 26-38. [CrossRef] [PubMed]

59. Chernitsyna, S.M.; Mamaeva, E.V.; Lomakina, A.V.; Pogodaeva, T.V.; Galach'yants, Y.P.; Bukin, S.V.; Pimenov, N.V.; Khlystov, O.M.; Zemskaya, T.I. Phylogenetic diversity of microbial communities of the Posolsk Bank bottom sediments, Lake Baikal. Microbiology 2016, 85, 672-680. (In Russian) [CrossRef]

60. Lomakina, A.V.; Mamaeva, E.V.; Galachyants, Y.P.; Petrova, D.P.; Pogodaeva, T.V.; Shubenkova, O.V.; Khabuev, A.V.; Morozov, I.V.; Zemskaya, T.I. Diversity of archaea in bottom sediments of the discharge area. Geomicrobiol. J. 2018, 35, 50-63. [CrossRef]

61. Hu, S.; Zeng, R.J.; Burow, L.C.; Lant, P.; Keller, J.; Yuan, Z. Enrichment of denitrifying a anaerobic methane oxidizing microorganisms. Environ. Microbiol. Rep. 2009, 1, 377-384. [CrossRef]

62. Lomakina, A.V.; Mamaeva, E.V.; Pogodaeva, T.V.; Kalmychkov, G.V.; Khalzov, I.A.; Zemskaya, T.I. Anaerobic methane oxidation in enrichment cultures from deep sediments of a mud volcano Peschanka (South Baikal). Microbiology 2018, 87, 317-325. (In Russian) [CrossRef] 
63. Zemskaya, T.I.; Lomakina, A.V.; Mamaeva, E.V.; Zakharenko, A.S.; Pogodaeva, T.V.; Petrova, D.P.; Galachyants, Y.P. Bacterial communities in sediments of Lake Baikal from areas with oil and gas discharge. Aquat. Microb. Ecol. 2015, 76, 95-109. [CrossRef]

64. Bol'shakov, A.M.; Egorov, A.V. On the application of phase equilibrium degassing for gasometric research in water areas. Okeanologiya 1987, 37, 861-862. (In Russian)

65. Pogodaeva, T.V.; Zemskaya, T.I.; Golobokova, L.P.; Khlystov, O.M.; Minami, H.; Sakagami, H. Chemical composition of pore waters of bottom sediments in different Baikal basins. Russ. Geol. Geophys. 2007, 48, 886-900. [CrossRef]

66. Pogodaeva, T.V.; Lopatina, I.N.; Khlystov, O.M.; Egorov, A.V.; Zemskaya, T.I. Background composition of pore waters in Lake Baikal bottom sediments. J. Great Lakes Res. 2017, 43, 1030-1043. [CrossRef]

67. Sambrook, J.; Fritsch, E.F.; Maniatis, T. Molecular Cloning. A Laboratory Manual, 2nd ed.; Cold Spring Harbor: New York, NY, USA, 1989.

68. Shubenkova, O.V.; Zemskaya, T.I.; Chernitsyna, S.M.; Khlystov, O.M.; Triboi, T.I. The first results of an investigation into the phylogenetic diversity of microorganisms in Southern Baikal sediments in the region of subsurface discharge of methane hydrates. Microbiology 2005, 74, 314-320. (In Russian) [CrossRef]

69. Holmes, A.; Costello, A.; Lidstrom, M.; Murrell, J.C. Evidence that particulate methane monooxygenase and ammonia monooxygenase may be evolutionarily. FEMS Microbiol. Lett. 1995, 132, 203-208. [CrossRef]

70. Sørensen, K.B.; Teske, A. Stratified communities of active archaea in deep marine subsurface sediments. Appl. Environ. Microbiol. 2006, 72, 4596-4603. [CrossRef]

71. Tamura, K.; Peterson, D.; Peterson, N.; Stecher, G.; Nei, M.; Kumar, S. MEGA5: Molecular evolutionary genetics analysis using maximum likelihood, evolutionary distance, and maximum parsimony methods. Mol. Biol. Evol. 2011, 28, 2731-2739. [CrossRef]

72. Quince, C.; Lanzen, A.; Davenport, R.J.; Turnbaugh, P.J. Removing noise from pyrosequenced amplicons. BMC Bioinform. 2011, 12, 38. [CrossRef]

73. Lomakina, A.V.; Pogodaeva, T.V.; Morozov, I.V.; Zemskaya, T.I. Microbial communities of the discharge zone of oil- and gas-bearing fluids in low-mineral Lake Baikal. Microbiology 2014, 83, 278-287. (In Russian) [CrossRef]

74. Kojima, H.; Tsutsumi, M.; Ishikawa, K.; Iwata, T.; Mußmann, M.; Fukui, M. Distribution of putative denitrifying methane oxidizing bacteria in sediment of a freshwater lake, Lake Biwa. Syst. Appl. Microbiol. 2012, 35, 233-238. [CrossRef]

75. Wang, J.; Cai, C.; Li, Y.; Hua, M.; Wang, J.; Yang, H.; Zheng, P.; Hu, B. Denitrifying anaerobic methane oxidation: A previously overlooked methane sink in intertidal zone. Environ. Sci. Technol. 2019, 53, $203-212$. [CrossRef]

76. Krylov, A.A.; Minami, H.; Hachikubo, A.; Shoji, H.; Khlystov, O.M.; Zemskaya, T.I.; Pogodaeva, T.V.; Kida, M.; Naudts, L.; Poort, J. Crystallization of authigenic carbonates in mud volcanoes at Lake Baikal. Geochem. Int. 2008, 46, 985-995. (In Russian) [CrossRef]

77. Holmer, M.; Storkholm, P. Sulphate reduction and sulphur cycling in Lake sediments: A review. Freshw. Biol. 2001, 46, 431-451. [CrossRef]

78. Klerkx, J.; Zemskaya, T.I.; Matveeva, T.V.; Khlystov, O.M.; Namsaraev, B.B.; Dagurova, O.P.; Golobokova, L.P.; Vorob'eva, S.S.; Pogodaeva, T.P.; Granin, N.G.; et al. Methane hydrates in surface layer of deep-water sediments in Lake Baikal. Dokl. Earth Sci. 2003, 393, 822-826. (In Russian)

79. Hu, S.; Zeng, R.J.; Keller, J.; Lant, P.A.; Yuan, Z. Effect of nitrate and nitrite on the selection of microorganisms in the denitrifying anaerobic methane oxidation process. Environ. Microbiol. 2011, 3, 315-319. [CrossRef]

80. Zhu, G.; Jetten, M.; Kuschk, P.; Ettwig, K.; Yin, C. Potential roles of anaerobic ammonium and methane oxidation in the nitrogen cycle of wetland ecosystems. Appl. Microbiol. Biotechnol. 2010, 86, 1043-1055. [CrossRef]

81. Klerkx, J.; De Batist, M.; Poort, J.; Hus, R.; Van Rensbergen, P.; Khlystov, O.M.; Granin, N. Tectonically Controlled Methane Escape in Lake Baikal. In The Geological Storage of Carbon Dioxide; Lombardi, S., Ed.; Springer: Berlin/Heidelberg, Germany, 2006; pp. 203-219.

82. Naudts, L.; Khlystov, O.; Granin, N.; Chensky, A.; Poort, J.; De Batist, M. Stratigraphic and structural control on the distribution of gas hydrates and active gas seeps on the Posolsky Bank, Lake Baikal. Geo Mar. Lett. 2012, 32, 395-406. [CrossRef] 
83. Ding, Z.; Ding, J.; Fu, L.; Zhang, F.; Zeng, R.J. Simultaneous enrichment of denitrifying methanotrophs and Anammox bacteria. Appl. Microbiol. Biotechnol. 2014, 98, 10211-10221. [CrossRef]

84. Wang, Y.; Zhu, G.; Harhangi, H.R.; Zhu, B.; Jetten, M.S.M.; Yin, C.; Op den Camp, H.J.M. Co-occurrence and distribution of nitrite-dependent anaerobic ammonium and methane-oxidizing bacteria in a paddy soil. FEMS Microbiol. Lett. 2012, 336, 79-88. [CrossRef]

85. Yang, J.; Jiang, H.; Wu, G.; Hou, W.; Sun, Y.; Lai, Z.; Dong, H. Co-Occurrence of nitrite-dependent anaerobic methane oxidizing and anaerobic ammonia oxidizing bacteria in two qinghai-tibetan saline lakes. Front. Earth Sci. 2012, 6, 383-391. [CrossRef]

86. Ishii, S.; Yamamoto, M.; Kikuchi, M.; Oshima, K.; Hattori, M.; Otsuka, S.; Senoo, K. Microbial populations responsive to denitrification-inducing conditions in rice paddy soil, as revealed by comparative 16S rRNA gene analysis. Appl. Environ. Microbiol. 2009, 75, 7070-7078. [CrossRef]

87. Ettwig, K.F.; van Alen, T.; van de Pas-Schoonen, K.T.; Jetten, M.S.M.; Strous, M. Enrichment and molecular detection of denitrifying methanotrophic bacteria of the NC10 phylum. Appl. Environ. Microbiol. 2009, 75, 3656-3662. [CrossRef] [PubMed]

88. Riedinger, N.; Formolo, M.J.; Lyons, T.W.; Henkel, S.; Beck, A.; Kasten, S. An inorganic geochemical argument for coupled anaerobic oxidation of methane and iron reduction in marine sediments. Geobiology 2014, 12, 172-181. [CrossRef] [PubMed]

89. Shen, L.; Ouyang, L.; Zhu, Y.; Trimmer, M. Active pathways of anaerobic methane oxidation across contrasting riverbeds. ISME J. 2019, 13, 752-766. [CrossRef] [PubMed]

(C) 2019 by the authors. Licensee MDPI, Basel, Switzerland. This article is an open access article distributed under the terms and conditions of the Creative Commons Attribution (CC BY) license (http://creativecommons.org/licenses/by/4.0/). 